\title{
Improving Primary Teacher Education Students' Writing Performance Using Flipped Classroom
}

\author{
Nurul Masyithah Rery ${ }^{1}$, Niamika El Khoiri ${ }^{1}$ \\ ${ }^{1}$ Pendidikan Bahasa Inggris-Universitas Negeri Malang
}

\section{INFO ARTIKEL}

\section{Riwayat Artikel:}

Diterima: 03-12-2019

Disetujui: 12-10-2020

\section{Kata kunci: \\ flipped classroom; \\ process writing; \\ flipped classroom; \\ proses menulis}

\author{
Alamat Korespondensi: \\ Nurul Masyithah Rery \\ Pendidikan Bahasa Inggris \\ Universitas Negeri Malang \\ Jalan Semarang 5 Malang \\ E-mail: masyithahrery@gmail.com
}

\begin{abstract}
ABSTRAK
Abstract: This study aimed to improve students' writing performance in ESP subject by implementing Flipped Classroom and Collaborative activities. Classroom action research was applied as the method in this study was. According to the data obtained, $88,89 \%$ of the students experienced improvement at least 10 points compared to their initial writing product. Students active participation also improved which was shown by the average score that was above 3,0 points obtained from peer assessment rubric. Therefore, the combination of these two strategies was proven successful in improving students' writing performance in ESP subject.

Abstrak: Penelitian ini bertujuan untuk meningkatkan kinerja menulis bahasa Inggris siswa sebagai mata pelajaran ESP dengan menerapkan kegiatan Flipped Classroom dan Collaborative. Metode yang digunakan dalam penelitian ini adalah penelitian tindakan kelas. Menurut data yang diperoleh, $88,89 \%$ dari siswa mengalami peningkatan setidaknya 10 poin dibandingkan dengan produk penulisan awal mereka. Partisipasi aktif siswa juga mengalami peningkatan yang ditunjukkan oleh skor rata-rata di atas 3,0 poin yang diperoleh dari rubrik penilaian sejawat. Dengan demikian, kombinasi dari dua strategi tersebut terbukti berhasil meningkatkan kinerja menulis bahasa Inggris siswa sebagai mata pelajaran ESP.
\end{abstract}

There are many hurdles with regards to the implementation of English for Specific Purpose at the university level. While it is taught thoroughly and carefully in English Department (ED), in non-English Department, English is taught without meticulous planning and control so students cannot learn the subject very well. As a result, graduates cannot develop their abilities and knowledge related to English when they graduate. Furthermore, there are at least two major problems were revealed during the classroom observation. It was found that the feedback given by the lecturer is not suitable for the level of university students. The lecturer only marked the students" writing with "good job", "awesome", "and very good". Somehow, some grammatical mistakes were still corrected with direct corrective feedbacks which did not trigger students to think more on how to correct their mistake independently. Moreover, due the large number of students in the class, during the face-to-face corrective feedback given by the teacher, the students tended to be noisy because the lecturer couldn't pay attention to the whole class, and those who have finished their assignment and waiting for their turn were busy with themselves rather than doing peer review with their friends.

From the questionnaire distributed through Google Form link, there were 63,7\% of students who strongly agreed that writing is the most complicated skill to master among four skills. The lack of practice and vocabulary was considered as the major challenge $(73,9 \%)$ followed by the lack of motivation in learning English since they are not English Department students $(21,7 \%)$. Concerning to the question about how they want to make the writing class be more interesting, most of them expected the lecturer to vary the teaching strategy (56,5\%). 91.3\% strongly agreed that they can use a learning application to help the learning process.

Looking at the phenomenon in which students were constantly playing with their phone rather than paying attention to the lecture should be taken as a teaching and learning opportunity to integrate the use of mobile phone into the teaching and learning process. Teachers and researchers need to realize the importance of assessing the process rather than the product in order to diminish writing apprehension. It is a challenge to look for another alternative that is comfortable and flexible learning environments. An innovative, effective and suitable teaching-learning strategy is therefore proposed by using flipped classroom to improve Primary Teacher Education students' writing performance. 
Giving the students the opportunities to write and create a lesson that enables them to experience an assortment of writing activities and instructions are alternatives to overcome writing problems. Somehow, students are still unsatisfied with the process although they have written and revised their draft numerous times during their writing because of the limited number of class sessions and inadequate time in the conventional classroom (So \& Lee, 2013). Hence, providing an adequate writing environments and opportunities for interacting and communicating with peer and teacher apathetic the time or place which combines the positive attributes of online and face to face instruction, known as flipped classroom is a promising alternative (Grgurovie, 2011; Hinkelman \& Gruba, 2012; Yoon \& Lee, 2010).

A flipped classroom, simply, reverse the lecture and the homework. In the other words, the writing assignments and exercises which usually accomplished at home are carried out in the class room and the teaching activity which usually given during the class session is arranged as homework through video lectures, reading tasks or other direct instruction delivery method. Nevertheless, this innovation has advanced into a further nuance shape of education

In common physical classroom, due to some constrains like big number of students, limited time, bunch of materials, students' lack of motivation make the students hard to continue their individual-regulated learning and contextual approach. The implementation of flipped classroom using a Course Management System (CMS) application helps students structure their learning tasks and allows them to provide formative feedback from both teacher and peer.

To runt flipped classroom requires a media to bridge the outside and inside classroom activities. Many media can be utilized in this case, such as social media like Facebook, Twitter, Wiki-blog, etc and CMS. CMS comprises a variety of online tools and environments, such as an area for teacher or lecturer members to post class materials such as course syllabus, handouts, lecture videos, an area to post papers and other assignments for students, a grade book where teacher or lecturer can record grades and students can see their grades, an integrated email tool allowing participants to send announcement email messages to the entire class or to a subset of the entire class, a chat tool allowing synchronous communication among class participants and a threaded discussion board allowing asynchronous communication among participants.

Due to the complex nature of English writing and its challenging conventions, both skilled and specifically unskilled learners usually have a sense of negative feeling and attitude toward this skill which is known as writing apprehension (Challob, Bakar, \& Latif, 2016). The students were panicked whenever their friends started to collect their works and approached the teacher to get the feedback. Consequently, they wrote carelessly without minding the linguistics features and accuracy. It is proven that writing apprehension leads to poor writing achievement. There are several factors why the apprehensive students always try to hide their writing in the classroom (Badrasawi, Zubairi, \& Idrus, 2016). Generally, the students felt anxious and worried due to time limitation and the lack of ability in conveying their ideas. Furthermore, it is unfair to judge students' writing ability according to a single piece of writing product that is written under a certain limited time condition and about the random unfamiliar topic. Thus, a single piece of writing cannot be used as a good indicator of students' overall writing ability (Roohani $\&$ Taheri, 2015).

Many have endorsed process writing (International Reading Association, 2009; National Association for the Education of Young Children, 2013; National Writing Project, 2014) which emphasizes in and concerns with the process for learning how to write like. The process-based writing approach does not take written expressions as a product. Instead, it is a teaching strategy for writing that reckons it as a process and benefits from the students' writing expression. It encourages the students to reveal what they think, what they do, what they take into consideration, and what kind of characteristics their writing contains (Arici \& Kaldirim, 2015).

Teachers implementing process writing involve in the process of writing with their students since they assist and guide the students during the process of producing the writing. In addition, through feedback, each student can improve the quality of his/her writing and internalize the stages within the entire process. Thus, students' writing skills can be developed.

\section{METHOD}

This research was conducted in primary school education study program in one of private universities in Malang where English was taught as an ESP course. There were 36 undergraduate students involved in this research. The researcher worked collaboratively with the lecturer of this class. The role of researcher was as the observer who took note during the classroom activity and as the second rater in scoring students' writing product.

There were two type of instruments employed to collect the data in this research namely scoring rubrics and peer assessment rubric which had been previously validated by two experts. This strategy was planned to have 4 meetings where the first meeting was used to introduce the students about this new strategy that was going to be implemented in their class.

There are three elements of the flipped classroom as pre-classroom learning activities, in-classroom learning or face to face activities, and assessment activities (McLaughin, White, Khanova, \& Yuriev, 2016). In this research the assessment was changed into revising/editing/self-reflecting of students' own writing assignment before publishing it to Edmodo. 
Table 1. Timeline of Strategy Implementation

\begin{tabular}{cclll}
\hline & \multirow{2}{*}{ Week I } & $\begin{array}{l}\text { Week II/ } \\
\text { Descriptive }\end{array}$ & $\begin{array}{l}\text { Week III/ } \\
\text { Procedure }\end{array}$ & $\begin{array}{l}\text { Week IV/ } \\
\text { Recount }\end{array}$ \\
\hline Pre-classroom activities & & Preparation & Preparation & Preparation \\
\hline \multirow{3}{*}{ Face to Face Activities } & \multirow{2}{*}{$\begin{array}{c}\text { Introduction to the } \\
\text { strategy }\end{array}$} & Meeting II & Meeting III & Meeting III \\
& & Planning & Planning & Planning \\
& & Drafting & Drafting & Drafting \\
\hline After classroom & & Revising/ Editing & Revising/ Editing & Revising/ Editing \\
Activities & & Publishing & Publishing & Publishing \\
\hline
\end{tabular}

The pre-classroom activities were reading material, watching video and note taking activities and were done outside the classroom as independent study. It was purposely designed that way so the students could be well prepared and ready when they came to the class. It allowed the students to recall and build their background knowledge better since these materials were not new and had been learned when they were in high school.

The rest of the three in-classroom or face to face meetings had the same pattern which started by reviewing what students had read, watching and taking notes from the uploaded material at Edmodo for 15 minutes. Then it was continued with the first process writing stage.

The first stage was planning. It is important for the teacher to select what kind of strategy that can be used in planning stage. Even though writing is an individual work, having the students to work in a group may broaden the chance to elaborate their writing since they can share, compare and contrast ideas and thought with their friends. To facilitate this stage, the researcher decided to choose collaborative writing activities. By having the students sit in group to discuss the topic together, it can trigger their background knowledge about the topic given.

In the group collaborative activities, each group consisted of four members. The activities were; first, together with the group, the members cluster the ideas that they were going to share and elaborate; second, the members shared equal workload and responsibility of their own task; third, the group was given time about 10 minutes to look for information of their task through internet; fourth, each member had turn approximately 4 to 5 minutes to share and respond their friend's idea; last, while listening to their friend's thought, they took a note to anything related to the topic as a prewriting activity. During the collaborative group activities, each member also assessed their peer performance by using the peer collaboration rubric. These activities were predicted to spend approximately 25 minutes.

Students who belonged to the same group had the same subtopics to be elaborated in their individual writing. Therefore, the students may share equal task among the group to find information about their subtopic before sharing it to the group. This activity made it easy for students to deepen the information needed because they only have to focus on completing their responsibilities. At the end of the collaborative activity session or planning stage, each student in the group already finished their prewriting since they also noted what they listened from their friends'.

The second stage was drafting. At this stage, the students already they knew the generic structure and the language feature of the text and they already had all the needed information which was obtained from the collaborative activity in form of prewriting shape. The students then started their individual drafting with this information. The students were given approximately 25 minutes for drafting stage.

The third stage was revising. As the students finished with their individual writing, they were instructed to ask for feedback from the group members who had the same topic to give feedback toward the content and organization components according to the peer feedback form given to them. The students were instructed to directly revise their draft straight after they received feedback from their friend.

The fourth stage was editing. At this stage, the revised draft was given to the teacher for more feedback dealing with the last three components namely vocabulary, language use and mechanic. Each of the students came to the lecturer with their revised draft. The lecturer then checked and marked the students' mistake with little notes to encourage the students to find the correct answer by themselves or discuss it with their friends. Even though the students only asked feedback for the thee required components, the teacher also frequently found mistake in the students' writing like the forgot to have the main idea of the sentence or not enough supporting sentence. Consequently, the teacher should also correct it for them.

As the classroom activities was over, the lecturer reminded the students to continue revising and editing the initial draft according to the feedback before publishing the final draft to the Edmodo group. The last stage was publishing. After revising and editing stage were finished, the students' were assigned to submit their final writing assignment to Edmodo group maximum three days after the face to face classroom activities so the researcher and lecturer could have their weekly meeting reflection to discuss the face to face classroom activities and to score or grade the final writing assignments. 
Table 2. Brief Description of Online and Offline Activities

\begin{tabular}{|c|c|c|c|c|c|c|}
\hline & Pre-class & & & In-class & & After-class \\
\hline Stages & Preparation learning & Planning & Drafting & Revising & Editing & Publishing \\
\hline Activities & $\begin{array}{l}\text { Learning, watching, } \\
\text { taking note, and making } \\
\text { question if any through } \\
\text { Edmodo. }\end{array}$ & $\begin{array}{l}\text { Discussing the } \\
\text { topic together } \\
\text { with the group }\end{array}$ & $\begin{array}{l}\text { Individual } \\
\text { drafting }\end{array}$ & $\begin{array}{l}\text { Giving/ taking feedback } \\
\text { for peer and revising the } \\
\text { draft according to the } \\
\text { received feedbacks. }\end{array}$ & $\begin{array}{l}\text { Taking the } \\
\text { revised/raw draft } \\
\text { and asking feedback } \\
\text { from teacher }\end{array}$ & $\begin{array}{l}\text { Posting the final } \\
\text { writing through } \\
\text { Edmodo. }\end{array}$ \\
\hline
\end{tabular}

There were two criteria that were set by the researcher. The first criterion was the students' achievement. At least $80 \%$ of the students should improve their writing score at least 10 points compared to the previous score they obtained from the preliminary study. The researcher decided this criterion considering that it was their first time utilizing technology in their learning process and the process writing as well. Moreover, the score these students got at the preliminary writing was quite low, with the highest scorer was 66 (fair) with mean 56,5 $(\mathrm{n}=36)$. Thus, this creation of success set was considered reasonable.

The second criterion was regarding to the students' active participation. At least $80 \%$ of the students should be actively involved during the process of the implementation of this strategy indicated by the score of 3,0. What was meant by being active were; first, participation where the group member fully participated and was always on task in class; two, leadership where the group member helping each other within the group to stay in track, encouraging group participation and have positive attitude; three, listening where the group member listen carefully to others' ideas; four, feedback where group member offered detailed, constructive feedback when appropriate; five, cooperation where the group member treated others respectfully and share workload fairly and last, time management where the group member completed the assigned tasks on time. To measure students' activeness, the researcher employed a peer assessment rubric.

\section{FINDING}

\section{Students' Writing Achievements}

The writing score for each student was the average from combination score of the two raters with the same scoring rubric. Since there were three writing assignments produced during the implementation stage this research, the compared score was the preliminary writing product to the last writing product which is recount text. If at least $80 \%$ of the students or 30 students $(n=36)$ get 10 points at the improvement, therefore the first criteria of success was achieved.

Table 3. Students' Score Improvement from Preliminary Writing to The Last Writing Assignment $(\mathrm{n}=36)$

\begin{tabular}{ccc}
\hline Score improvement & Number of students & Percentage \\
\hline$>10$ & 30 & $83,33 \%$ \\
10 & 2 & $5,56 \%$ \\
$<10$ & 4 & $11,11 \%$ \\
\hline
\end{tabular}

From table 3 , it can be seen that $83,33 \%$ of students whose improvement above 10 points and only $5,6 \%$ whose improvement were 10 points. It means that $88,89 \%$ or 32 students successfully achieved the target. There was no test at the end of the cycle in this strategy. The students' writing products from every meeting were scored and graded by the lecturer and the researcher to see students' improvement from meeting to meeting in the implementation of process writing combined with Edmodo.

Table 4. Students' Writing Level from Meeting to Meeting $(n=36)$

\begin{tabular}{lcccc}
\hline Writing level & Preliminary & Meeting II & Meeting III & Meeting IV \\
\hline Very Good & 0 & 0 & 0 & 2 \\
Good & 0 & 0 & 20 & 23 \\
Fair & 8 & 20 & 16 & 11 \\
Poor & 28 & 16 & 0 & 0 \\
Very Poor & 0 & 0 & 0 & 0 \\
\hline \multicolumn{1}{c}{ Mean } & $\mathbf{5 6 . 5 0}$ & $\mathbf{5 9 . 3 9}$ & $\mathbf{7 0 . 2 8}$ & $\mathbf{7 2 . 3 9}$ \\
\hline
\end{tabular}

As can be seen from table 4, at the preliminary writing, there were 8 students at fair level and 28 students at poor level. It indicated that the students' proficiency level of this class was also at poor level where the mean was 56,50. At the second meeting, the number of students at fair level was increased to 20 students and the students who were at poor level was decreased to 16 students where the mean was also improved became 59,39. At the third meeting, 20 students moved to higher writing level which was good level and 16 students at fair level where the mean was 70,28. At the last meeting, 2 students moved to the higher level which is very good level, 23 students at good level and 11 students at fair level and none of them left at poor level with mean was 72,39 . From the preliminary writing to the last writing product, the mean improvement was increased from 
56,50 to 72,39. Meaning that each of the students experience score improvement approximately 15,89 points from the preliminary to the last writing product.

Dealing with every component of writing (content, organization, language use, vocabulary and mechanics), the data analysis result indicated that the students' ability in writing various type of texts had significantly improved from meeting to meeting. The score after the implementation of this strategy showed that the students made improvement in all components of writing. As can be seen in table 5 , students made improvement from meeting to meeting.

Table 5. Writing Components Improvement from the Preliminary Writing to the Last Writing Product $(\mathbf{n}=36)$

\begin{tabular}{lccccc}
\hline & \multicolumn{5}{c}{ Writing Components } \\
\cline { 2 - 6 } & Content & Organization & Language Use & Vocabulary & Mechanic \\
\hline Preliminary & 3,39 & 3,31 & 2,36 & 2,50 & 2,57 \\
Meeting II & 3,60 & 3,30 & 2,50 & 2,70 & 2,70 \\
Meeting III & 4,10 & 4,10 & 3,20 & 3,20 & 2,90 \\
Meeting IV & 3,90 & 4,00 & 3,60 & 3,30 & 3,30 \\
\hline
\end{tabular}

From table 5 above, it can be seen that the mean score of the first component which is content is improved by 0,51 points from 3,39 at the preliminary writing became 3,90 at the last writing product. The second component, which is organization improved by 0,69 points from 3,31 at the preliminary writing to 4,00 at the last writing product. The third component is language use or grammar which improved by 1,24 points from 2,36 at the preliminary writing to 3,60 at the last writing product. The next component is language use which also had improvement by 0,80 points from 2,50 at the preliminary writing to 3,30 at the last writing product. The last component is mechanics which improved by 0,73 points from 2,57 at the preliminary writing to 3,30 at the last writing product.

\section{Students' Active Participation}

The second analyzed data was the average calculation of peer assessment collaboration rubric from every meeting. If at least $80 \%$ of the students or 30 students $(n=36)$ get 3.0 point, it means that the second criteria of success was achieved.

Table 6. Average Score of Students' Active Participation $(n=36)$

\begin{tabular}{ccc}
\hline Score & Number of Students & Percentage \\
\hline$>3,0$ & 29 & $80,56 \%$ \\
3 & 3 & $8,33 \%$ \\
$<3$ & 4 & $11,11 \%$ \\
\hline
\end{tabular}

From table 6 above, it can be seen 29 students or $80,56 \%$ of the students get point above 3,0 and only 3 students $8,33 \%$ of the students get 3,0 . It means that 32 students or $88,89 \%$ of the students were successfully contributed to the achievement of the second criterion of success.

For the students' active participation, according to the observation that the researcher had done, it had been started since the first meeting where this new strategy implementation was introduced to the class. The researcher noted that the students seemed and felt more excited knowing the fact that they were allowed to take and continue their writing assignment at home and upload it through Edmodo. Moreover, because the materials were uploaded at Edmodo the students were more prepared and felt confident coming to the class. It can be seen that some of the students printed the material and the rest accessed it from their phone or laptop.

As the reviewing activities begun, the multi-ways communication was seen when the students actively responded to the lecturer's questions about what have they learnt and if the faced any difficulties. When the students asked something, the lecturer did not directly answer the student' question but threw it to the class for the answer. These warming up activities went smoothly as planned and the students were ready for the next coming activities.

The students' active participation score improvement was affected by the implementation of collaborative activities at the planning stage of process writing before conducting the initial draft. It played a vital role in improving students' achievement in writing. It was used as a technique to build and to recall students' background knowledge about the given topic together with the group. Moreover, this technique was included to support student-centered learning because the main classroom agenda was no longer about the lecturer explaining the material but assisting the students with more meaningful activities like this group collaborative activities. At the end of the group collaborative activities, every group produced one sketch or cluster that was used together by the members as the basic thought of what they should write in the individual draft. 


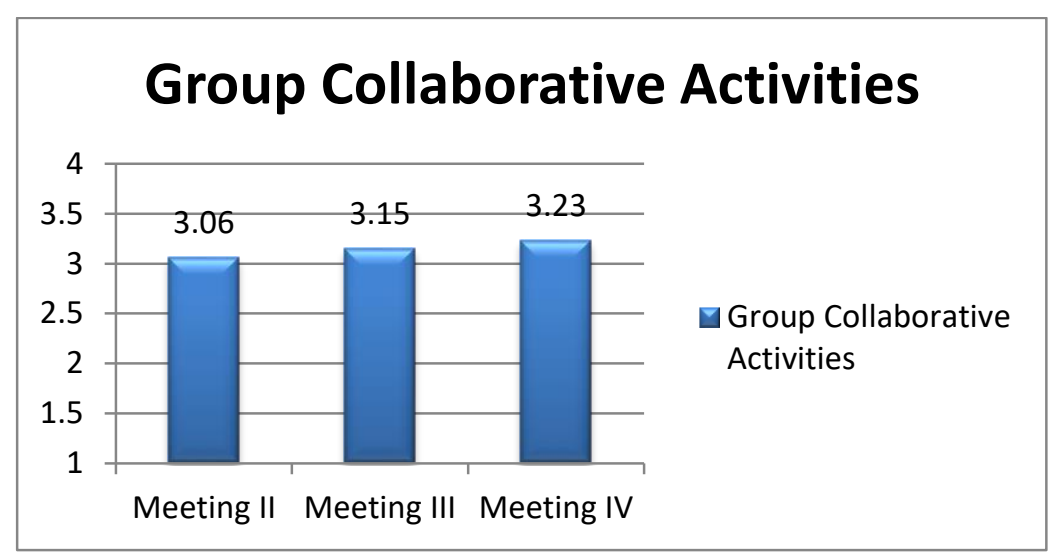

Figure 1. Students' Average Score in Collaborative Activities

As shows in figure 1, it can be seen that there are significant improvements of the students' active participation from meeting to meeting. The numbers in the graph shows a good indication that the students were actively engaged and more active from meeting to meeting during the process of the collaborative activities even though almost all the students still using Bahasa Indonesia in communicating or presenting the idea. It cannot be denied that these students fluency in speaking English is still low. On the other hand, what was assessed during the collaborative activities was not the fluency in communicating the idea so it did not matter what language they used as long as they wrote the result in English.

Furthermore, the improvement of the students' active participation was caused by the awareness that they were being assessed by every members of the group; they forced themselves to present the best they could. Therefore, some students in each group seemed to dominate the group discussion, some member just kept silent and listened to their friend's idea while writing it down. For this case, at the weekly reflection between the researcher and the lecturer, the researcher suggested the lecturer to remind the students to have equal portion and chance in every indicator written in the peer assessment rubric.

The finding from the students' writing achievement and the peer collaboration scores shows that there were significant improvements from the second to the fourth meeting which indicated that the implementation of this strategy is succeeded in improving students' writing performance.

\section{DISCUSSION \\ Students' Writing Improvement}

The finding of this research showed that there were improvements on the students' writing ability in several types of text namely descriptive, procedure and recount texts within three meetings. These improvements could be seen not only from the final writing assignments that the students posted at Edmodo group but also from the process to produce the writing itself. The findings also resemble and strengthen to the findings of several previous researches which focused on the implementation of flipped classroom, Edmodo, process writing, group collaborative activities and feedback. In addition, the researcher also has several assumptions and interpretations regarding the successful implementation of this strategy.

According to the findings, almost all of the students experienced improvement in their writing skill in various types of long functional text namely descriptive, procedure and recount. In regard of flipped classroom, the implementation of this strategy was effective in improving students' writing ability. This findings corresponds to the findings of several previous researches which focused on the implementation of flipped classroom in the same skill which stated that flipped classroom instruction can contribute to the improvement of students' grade on English writing proficiency (Mireille, 2014; Mokhtar, 2018) and the process writing approach has positive influence on non-English majors' writing ability and is effective in improving their writing ability (Zhou, 2015). The first activity of the implementation of this strategy is the structured assignment which considered as the preparation activity. Pre-class learning dimension of flipped classroom is largely benefitted from technological advancement, in this case is Edmodo, is crucial in term of preparing the students for in-class learning (Adnan, 2017). Edmodo enables students to access learning resources beyond the classroom and empowering student-centered learning through novelty of tasks, suitable learning environment, and mobility (Mokhtar, 2018).

The lecturer provides the learning material in Edmodo and instructs the students to learn the material, watch youtube videos from the link attached in the document, take notes, make question if any. These activities encourage autonomous learning since each student has been given responsibilities for watching the video-lectures as homework. It is believed that this can help them to be more autonomous learners (Ekmekci, 2017). Flipped classes enhanced learning through in-class engagement, providing time/opportunity for real-life applications, and encouraging social classroom learning (Adnan, 2017). As stated in (Qader \& Arslan, 2015), flipped classroom can provide an enriched learning environment enabling these learners' autonomy and increasing their motivation. 
Through the writing process, students are automatically encouraged to maximize their abilities such as skills and knowledge by benefitting the provided assistance and guidance given by the teacher and cooperation and collaboration from their peers. It reassures them to freely write their thoughts and ideas since they are already provided with sufficient time and opportunity to revise and edit their writing with the help of their peer and teacher (Onozawa, 2010). Process writing surely has brought a good impact on students' writing performance as well as on as on punctuation, spelling, correct usage of capitals, tenses, subject-verb compliance, tenses, pronouns, possessive pronouns and conjunctions (Pasand \& Haghi, 2013; Qader \& Arslan, 2015). Moreover, not only for professional writers, process writing also brings affirmative effect in low-level classrooms and self-confidence of the students as well as the improvement of their writing capabilities (Ho, 2006)..

The core of flipped classroom lies in students and teacher engagement in an active learning experience in class (Adnan, 2017). In the current study, the form of engagement lies in the classroom or in the offline meeting activities. It starts from the first lecturer reviews what the students have learnt from the material given, question and answer session where the lecturer encourages the class to answer the classmate's question, the collaborative activities in the planning stage, the peer feedback activity. The thing most encouraged in the application of flipped classrooms is to change class activities into student-centered activities which require teacher assistance in form of collaborative activity (Ekmekci, 2017). Process writing encourages collaborative group work between students as a way of improving motivation and developing positive attitudes towards writing (Nunan, 1991). When various group activities are utilized in writing classes, it allows students to exchange comments or responses, or work together to write a paragraph or an essay (Onozawa, 2010). For this sake, collaborative group activities were utilize to facilitate the planning stage of process writing.

Each group member had their own responsible part to be discovered before sharing it to the group since students could be the source of information (Moore \& Teather, 2013). A collaborative environment in which students are encouraged to critically analyze resources while gaining knowledge through self-discovery and instructor guidance is the backbone of the inclass portion of flipped classroom (Qader \& Arslan, 2015). Here, besides sharing, the other group member may respond their friend thought by arguing their opinion (Arnold-Garza \& Towson University, Albert S. Cook Library, 2014). Moreover, by asking them to work in groups, it is believed that each student can observe nuances as he/she demonstrates what each student picked up (or didn't) from the tutorials (Borchardt, 2012).

The result of the collaborative group activities is in a form prewriting shape which the group members took/wrote during the group discussion. Therefore, each member of the group has the same points to be elaborated or explained with their own language style. What is most emphasized in this prewriting is the fluency of students in summarizing all the information conveyed by the group member without minding the correctness of grammar, dictions or mechanics because the aim of putting their ideas into sentence is greater than correcting the errors (Faraj, 2015). This prewriting shape is used as a guide for drafting stage. At drafting stage, students reread and start to write carefully all the information gathered according to the prewriting and pay attention to the generic structure and language feature of the text type.

On the basis of the feedback given by peer in the revising stage, the draft is revised for the content and organization of the ideas focusing on unity, support/detail, and coherence (Dilidüzgün, 2013). The revision is best done while still in the group since it allows the negotiation of meaning by communicate it directly with their friend when there are comments that are not understood by students. While most of the time in writing class, students work individually without interacting with one another, thus, if they are given time to communicate with their classmates about their products orally, learners will be able to express their own opinions and exchange ideas. The result will be a comprehensive improvement in their language skills (Onozawa, 2010).

Editing stage deals with "how you write" and the draft is checked for spelling, punctuation, and parallelism in the structures, style, grammar, and accuracy of supportive textual material such as quotations (Dilidüzgün, 2013) according to the feedback that is given by teacher. The final writing assignment may be posted at Edmodo group as the students finished their own reflection toward their writing.

\section{CONCLUSIONS}

According to the finding of this research and discussion, three criteria of success have been successfully achieved within one cycle. Henceforth, the researcher stops the treatment. Three conclusions can be drawn which in line with the achievements of the criteria of success. First, the implementation of Flipped classroom combined with process writing have successfully improved the students' achievements in writing three long functional texts namely descriptive, procedure and recount texts. Second, students' active participation during classroom ad group activities is also improved during the classroom activities. Last, students shows positive attitude toward the implementation of this strategy.

There are at least three suggestions suggested in this research. First, Edmodo as the online platform was only used as a place to provide/take the learning material and publish students' final writing assignment which researcher considers as a weakness of this strategy. Therefore, it is suggested to maximize the use if Edmodo's features by having other supplementary activities such as adding quizzes or mini test outside classroom activities which can be conducted through Edmodo. It aims to measure the students' gap of what they missed so the lecturer could prepare what should they do in the next meeting to fill it. 
Second, it is suggested to focus on certain type of text. In the current study, the researcher used different type of text from meeting to meeting since it was constructed that way in the course outline by the lecturer. The same pattern of strategy implementation may only be applied in the same situation where the students have already used to with the materials namely descriptive text, procedure text and recount text.

Last, to see whether the students really revise and edit their initial draft based on the peer and teacher feedback before publishing their final writing assignments at Edmodo, it is suggested for future researcher to ask the students to keep and collect their first draft and peer and teacher feedback sheet in the next meeting. Therefore, the raters can compare students' draft and the final writing assignment that they publish if there are any changes or not. This suggestion is due to the frequent errors that are found in students' final assignments.

\section{REFERENCES}

Adnan, M. (2017). Perceptions of senior-year ELT students for flipped classroom: A materials development course. Computer Assisted Language Learning, 30(3-4), 204-222.

Arici, A., \& Kaldirim, K. (2015). The Effect of the Process-based Writing Approach on Writing Success and Anxiety of Preservice Teachers. Anthropologist, 22(2), 318-327.

Arnold-Garza, S., \& Towson University, Albert S. Cook Library. (2014). The Flipped Classroom Teaching Model and Its Use for Information Literacy Instruction. Comminfolit, 8(1), 7.

Badrasawi, K. J., Zubairi, A., \& Idrus, F. (2016). Exploring the Relationship between Writing Apprehension and Writing Performance: A Qualitative Study. International Education Studies, 9(8), 134-143.

Borchardt, R. (2012). Adventures in library instruction podcast.

Challob, A. I., Bakar, N. A., \& Latif, H. (2016). The Influence of Blended Learning on EFL Students' Writing Apprehension and Writing Performance: A Qualitative Case Stud. European Journal of Multidisciplinary Studies, 1(2), $253-265$.

Dilidüzgün. (2013). The Effect of Process Writing Activities On The Writing Skills Of Prospective Turkish Teachers. Egitim Arastirmalari -Eurasion Journal of Educational Research, 52, 189.

Ekmekci, E. (2017). The Flipped Writing Classroom in Turkish EFL Context: A Comparative Study on A New Model. Turkish Online Journal of Distance Education, 151-151.

Faraj, A. K. A. (2015). Scaffolding EFL Students' Writing through the Writing Process Approach. Journal of Education and Practice, 6(13), 131-143.

Grgurovie, M. (2011). Blended Learning in an ESL Class: A Case Study. Calico Journal, 29(1), 111-132.

Hinkelman, D., \& Gruba, P. (2012). Power within Blended Learning Programs in Japan. Language Learning \& Technology, $16(2), 46-64$.

Ho, B. (2006). Effectiveness of Using the Process Approach to Teach Writing in Six Hong Kong Primary Classrooms. Perspectives: Working Papers in English and Communication, 17(1), 1-52.

McLaughin, J. E., White, P. J., Khanova, J., \& Yuriev, E. (2016). Flipped Classroom Implementation: A Case Report of Two Higher Education Institutions in the United States and Australia. Computers in the Schools, 33(1), 24-27. https://doi.org/10.1080/07380569.2016.1137734

Mireille, F. (2014). The Impact of Using a Flipped Classroom Instruction on the Writing Performance of Twelfth Grade Female Emirati Students in the Applied Technology High School (Aths) (Master Thesis). The British University, Dubai.

Mokhtar, F. A. (2018). Breaking Barriers Through Edmodo: A Qualitative Approach on the Perceptions of University of Malaya Undergraduates. Online Learning, 22(1).

Moore, C., \& Teather, S. (2013). Engaging Students in Peer Review: Feedback as Learning. Issues in Educational Research, 23(2), 196-211.

National Association for the Education of Young Children. (2013). Position statement-Developmentally Appropriate Practice. Washington, DC.

Pasand, P. G., \& Haghi, E. B. (2013). Process-Product Approach to Writing: The Effect of Model Essays on EFL Learners' Writing Accuracy. International Journal of Applied Linguistics \& English Literature, 2(1), 76-79.

Qader, R. O., \& Arslan, F. Y. (2015). The Effect of Flipped Classroom Instruction in Writing: A Case Study with Iraqi EFL Learners. Teaching English with Technology, 19(1), 36-55.

Roohani, A., \& Taheri, F. (2015). The Effect of Portfolio Assessment on EFL Learners' Expository Writing Ability. Iranian Journal of Language Testing, 5(1), 46-59.

So, L., \& Lee, C. H. (2013). A Case Study on the Effect of an L2 Writing Instructional Model for Blended Learning in Higher Education. Turkish Online Journal of Educational Technology, 12(4), 1-10.

Yoon, S. Y., \& Lee, C. H. (2010). The Perspectives and Effectiveness of Blended Learning in L2 Writing of Korean University Students. Multimedia-Assisted Language Learning, 13(2), 177-204.

Zhou, D. (2015). An Empirical Study on the Application of Process Approach in Non-English Majors' Writing. English Language Teaching, 8(3), 89. https://doi.org/10.5539/elt.v8n3p89 